\title{
Preparing Students for Success in STEM: Role of Professional Societies
}

Irene V. Hulede*

Education Department, American Society for Microbiology, Washington, DC 20036
$M$ y passion in higher education administration stems from my interest in working with trainees at all levels to advance their educational and career endeavors. In my current position as the senior manager for education at the American Society for Microbiology (ASM), I have had the opportunity to manage several fellowship programs, courses, and conferences that focus on broadening participation. The need for such programs has been well described (e.g., American Council on Education, 2005; National Academy of Sciences, National Academy of Engineering, and Institute of Medicine, 2007, 2011; Council on Undergraduate Research, 2009). A significant portion of the U.S. population comes from three underrepresented minority (URM) groups, Hispanics (16\%), Blacks/African Americans (12\%), and Native Americans (1\%), yet they remain a small percentage of the science and engineering workforce. More must be done to prepare a future scientific workforce that reflects the U.S. population spectrum and takes advantage of the competitive advantage of diverse groups (Page, 2007).

Scientific societies are key partners in accomplishing this goal. As the long-term professional homes of their members, societies facilitate community building, represent the concerns of the community, and offer programming for individuals that may not be offered by academic institutions or government agencies. Here, I will describe how ASM has operated to broaden participation and maximize diversity in the life sciences by highlighting a unique program: the Annual Biomedical Research Conference for Minority Students (ABRCMS).

Since 2000, ASM has partnered with the National Institutes of General Medical Sciences to organize this multidisciplinary conference. ABRCMS has been designed to meet the needs of students from URM backgrounds as they prepare for and enter into successful scientific careers, with such needs including

- identifying good mentors;

- networking with peers and role models;

- finding and securing funding for research opportunities and additional professional development;

- presenting research and receiving critical feedback from experts in the field;

- integrating into the larger scientific community;

- exploring further education and development through postbaccalaureate, graduate, and postdoctoral programs; and

- exploring diverse career pathways for scientists.

ABRCMS aims to build science identity by providing students the chance to network with peers who may have had similar experiences and to connect with role models who can help students solidify a vision of future success for themselves. The conference also provides opportunities for students to present their research-further developing science identity and self-efficacy. The conference draws world-renowned scientists who share their work with students as junior colleagues. These scientists also give feedback to students and serve as their mentors.

A recent study of juniors and seniors who attended the conference demonstrated its impacts (Casad et al., 2017). Frequency of attending or presenting at ABRCMS was
Kenneth Gibbs, Monitoring Editor

Submitted Nov 28, 2017; Revised Jun 22, 2018; Accepted Jun 25, 2018

CBE Life Sci Educ September 1, 2018 17:es14 DOI:10.1187/cbe.17-11-0243

*Address correspondence to: Irene V. Hulede (ihulede(aasmusa.org).

(c) 2018 I. V. Hulede. CBE-Life Sciences Education @ 2018 The American Society for Cell Biology. This article is distributed by The American Society for Cell Biology under license from the author(s). It is available to the public under an Attribution-Noncommercial-Share Alike 3.0 Unported Creative Commons License (http://creativecommons.org/licenses/ by-nc-sa/3.0)

"ASCB $®$ " and "The American Society for Cell Biology ${ }^{\prime}$ " are registered trademarks of The American Society for Cell Biology. 
positively related to science self-efficacy, research confidence, sense of belonging in science, and intentions to pursue a research degree in graduate school. While attendees from all backgrounds benefited from ABRCMS, students from URM backgrounds had higher science self-efficacy and sense of belonging in science after attending ABRCMS compared with non-URM students. To me, ABRCMS is more than just a 4-day conference-it is a place where scientific careers begin.

ABRCMS continues to grow, presenting new challenges for us as conference organizers. The number of student presentations increases by 3-5\% each year, requiring more effort for recruiting an adequate number of judges and mentors. With the decrease in research funding, many research faculty who serve as judges, mentors, and role models would not be able to attend without subsidies from ABRCMS.

The conference has in recent years broadened its focus to include students from other backgrounds who have representational challenges in biomedicine, including students with disabilities and students from community colleges. Careful attention is paid to incorporating programming and resources that specifically address the needs of students from these groups, which sometimes comes with significant budgetary implications as well as logistical requirements. These requirements include the costs of interpreters or other such necessities. We are careful not to generalize the needs of underrepresented groups or assume that everyone has similar experiences.

Along these lines, our programming is increasingly structured to account for the unique stories and experiences of individuals and groups. For example, in recent years, we have devoted special attention to minority students at research-intensive institutions where the URM populations are often smaller than at minority-serving institutions and students may not have large support systems. Oftentimes, these students feel more alone than those at minority-serving institutions and are hungry to identify a community of support. Conferences such as ABRCMS, and the annual conference of the Society for the Advancement of Chicanos and Native Americans in Science, provide nurturing environments for students and scientists from underrepresented groups outside their own institutions. In addition, the societies hosting these conferences become a scientific home for these individuals once they graduate and their scientific careers progress.

The scientific community will best be able to capitalize on the resources of professional societies such as ABRCMS and their unique positioning to broaden participation in the scientific enterprise if

1. Diversity and inclusion are primary missions and goals of the professional society. This means, at a minimum, devoting resources and setting goals so that each unit of the organization is held accountable for increasing diversity throughout the organization's program and activities. For example, at ASM, attaining diversity and inclusion is an important strategic goal for the organization, and each committee within the organization must ensure that diversity and inclusion are incorporated in all its programming (see www.asm.org/ index.php/governance/strategic-plan).

2. Professional societies take an active role in recruiting underrepresented minority trainees as members. Many undergraduate students may not fully grasp the importance of joining their respective disciplinary societies. For example, after ABRCMS, students-especially undergraduate seniors and early graduate-level students-are encouraged to transition into their respective disciplinary society communities and attend their national meetings. Additionally, several of the sponsoring societies, including ASM, offer travel support for students attending ABRCMS to attend annual disciplinary society meetings. In addition to conducting focus group sessions and discussions/ workshops on diverse career pathways, many societies sponsor scientific sessions, and members serve as judges to advise students about career trajectories. Such programming helps build diversity in a variety of science, technology, engineering, and mathematics (STEM) disciplines and introduces the students to a broader community of practice in their fields. ASM makes a concerted effort to diversify its membership by attending and recruiting at branch and regional meetings and offering fellowships that specifically target URM groups, seeking members who would likely serve as mentors and role models to future scientists. Moreover, ASM strives to ensure diverse representation on all committees and boards. For example, in addition to the previously mentioned efforts focused on URM populations, ASM has put new energy into building partnerships with community college faculty and leaders, as these institutions serve as the starting ground for many URM students who are interested in STEM (Hewlett, 2018).

3. Professional societies aim to develop the mentoring networks of students and mentoring capabilities of scientists. It is important to emphasize the need for multiple mentors and a tiered mentoring system to achieve successful outcomes in the area of broadening participation (Montgomery, 2017). Several ways that societies can lead include 1) building tools and strategies for exploring effective mentoring interventions with a broad range of individuals from a specific discipline, 2) developing a mentoring network, 3) providing mentor/mentee training, and 4) disseminating best practices of building and cultivating mentoring activities and networks.

Although a lot of work has already been done to advance diversity and inclusion, there is still much more work to do. To date, small groups of individuals who are committed to the cause have served as advocates. To effect broader and sustained change, diversity and inclusion must be emphasized and infused in every program and every organization. Scientific societies serve as hubs to amplify such efforts throughout their respective disciplines. To build and sustain impactful programs over time, effective evaluation must be an integral part of such efforts to support continuous improvement and promotion of intended outcomes. Professional societies can lead the way by modeling this in their work and providing effective tools, support, and networking to current and future generations of scientists.

\section{ACKNOWLEDGMENTS}

I acknowledge Amy Chang, ASM Education Director, for her advice, guidance, and support of ASM's programs. 


\section{REFERENCES}

American Council on Education. (2005). Increasing the success of minority students in science and technology. Washington, DC.

Casad, B., Chang, A., \& Pribbenow, C. (2017). The benefits of attending the Annual Biomedical Research Conference for Minority Students (ABRCMS): The role of research confidence. CBE-Life Sciences Education, 15(3) ar46. https://doi.org/10.1187/cbe.16-01-0048

Council on Undergraduate Research. (2009). Broadening participation in undergraduate research: Fostering excellence and enhancing the impact. Washington, DC.

Hewlett, J. A. (2018). Broadening participation in undergraduate research experiences (UREs): The expanding role of the community college. CBE-Life Sciences Education, 17(3), es9.
Montgomery, B. (2017). Mapping a mentoring roadmap and developing a supportive network for strategic career advancement. SAGE Open, 7, 2. https://doi.org/10.1177/2158244017710288

National Academy of Sciences, National Academy of Engineering, and Institute of Medicine. (2007). Rising above the gathering storm. Washington, DC: National Academies Press.

National Academy of Sciences, National Academy of Engineering, and Institute of Medicine. (2011). Expanding underrepresented minority participation: America's science and technology talent at the crossroads. Washington, DC: National Academies Press. https://doi.org/10.17226/12984

Page, S. (2007). The difference: How the power of diversity creates better groups, firms, schools, and societies. Woodstock, UK: Princeton University Press. 